\title{
Evaluation of acute and sub-acute hepatotoxic activity of leaves of Ehretialaevis n-hexane extract in mice
}

\author{
Nadia Perveen ${ }^{1}$, KhwajaZafar Ahmed ${ }^{1}$, Sohail Ahmad², Qura-tul-Ain ${ }^{3}$, Muhammad \\ Shoaib $^{4}$, Sadia Ashraf ${ }^{5}$, Shaneel Kausar ${ }^{5}$, Aisha Shehzad ${ }^{5}$, Amber Shafi ${ }^{5}$, \\ Ayesha Babar ${ }^{6}$, Faiza Naseer ${ }^{1,4^{*}}$ \\ ${ }^{1}$ College of Pharmacy, Government College, University, Faisalabad, Pakistan \\ ${ }^{2}$ Department of Biochemistry, Hazara University, Mansehra, Pakista \\ ${ }^{3}$ Department of Biochemistry, Quaid-e-Azam University, Islamabad, Pakistan \\ ${ }^{4}$ Department of Medical Technology, ShifaTameer e Millat University H-8/4 Islamabad, Pakistan \\ ${ }^{5}$ Department of Physiology and Pharmacology, Agriculture University, Faisalabad, Pakistan \\ ${ }^{6} \mathrm{MSPH}, \mathrm{Al}$ Shifa school of Public Health, Rawalpindi, Pakistan
}

\begin{abstract}
Objective:The aim of the present study was to evaluate the acute and subacute hepatotoxicity of Ehretialaevis (leaves). Methods: Toxicity study of Ehretialaevis was carried out in Swiss female mice after singleingestion of the extract at different doses (acute toxicity) and daily administration forfifteen days (subacute toxicity). Results: The results showed that the $\mathrm{LD}_{50}$ of the extract was higher than $4000 \mathrm{mg} / \mathrm{kg}$ and subacute treatment showed no change in weight of liver however, ALT, ALP, AST bilirubin and globulin values increased significantly whereas albumin and protein decreased.Histopathological studies showed aggregation of cells in parenchyma and in blood vessels vicinity at $1000 \mathrm{mg} / \mathrm{kg}$. At $2000 \mathrm{mg} / \mathrm{kg}$ vacuolation was present, sinusoidal spaces absent, acute cellular swellingand mild degree of cell necrosis was noted. At $4000 \mathrm{mg} / \mathrm{kg}$ cellular swelling was found to be increased and large number of polymorphic cells was present in blood vessels, showing necrosis. Extract showed dose related toxic effects on hepatocytes.Conclusions:On the basis of above findings it is concluded that the n- hexane extract of leaves of Ehretialaevis has hepatotoxic effect in mice. Further, chronic toxicity studies are needed in other species and with different extract.
\end{abstract}

Keywords: Ehretialaevis, n-hexane, mice, hepatotoxicity.

\section{INTRODUCTION}

Ehretialaevis is found world widely in India, China, Australia and Pakistan (Joshi, 2000), locallyavailable in Kashmir and Lahore. Local name ofthe plant is Chamror and Tamboliya. Its leaves are chewed to cure mouth blisters.For the cure of dysuria leaf powder is taken orally by mixing with sugar and goat milk for 10 days(Jain et al., 2008). Leaves paste is appliedlocally in headache, ulcer (Joshi, 2000) and eczema. Flower powder acts as aphrodisiac when taken with milk. Fruit of plant acts as anthelmintic, astringent, demulcent, diuretic, expectorant and also helps in urinary passage affections, lungs and spleen diseases (Joshi, 2000). Fresh root decoction issued for syphilis and bark of stem for diphtheria. E. laevis soaked seeds are ground to make paste, mixed with large cardamomum (Amomumsubulatum) and taken with milk orally for the cure of jaundice (Sharma et al., 2012). Seeds act as anthelmintic (Joshi, 2000). To cure ringworms, powder of kernel is mixed with oil and applied on the affected part. Leaves of the plant contain carbohydrates, proteins, fats, vitamins A, C, E, thiamine and Riboflavin (Torane et al., 2010; Saleem and Naseer, 2014).Stem and leaves ethanol extract of E. laevisshows significant antioxidant activity (Rasika et al in 2011).According to study by Toran\& coworkers in 2011, flavonoids and phenolic contents inmethanol extract of E.laevisleaves shows antioxidant activity in vitro by using 2, 2-diphenyl-1-picryl-hydrazyl (DPPH), the study extended with n-hexane extract (Saleem et al., 2015).In current study n- hexane extract of Ehretialaevisleaves are investigated for acute and subacute toxicity as there is no prevention report for evaluation of its toxicity. 


\section{Materials ANd Methods}

\section{Plant material and extraction}

Leaves of the plant used in experimental work were collected from botanical garden of GC University Lahore, Pakistan. The plant Ehretialaevis was compared with the voucher specimen (voucher specimen No.GC Herb. Bot 2288) deposited at Botany Herbarium at G.C. University Lahore. The leaves were washed with tap water; shade dried, powdered and soaked in n-hexane (Perianayagam et al., 2011) for seven days. Extract was prepared by simple maceration process using $5 \mathrm{~L}$ of $\mathrm{n}$-hexane. Extract was evaporated under reduced pressure using rotary evaporator.

\section{Animals}

Thirty Swiss female mice of same age group weighing 25-30g were purchased from National Institute of Health Sciences Islamabad, Pakistan. They were maintained at Animal House of College of Pharmacy G.C. University Faisalabad. They were kept in the cages, had free access to food and waterad libitum and maintained under controlled temperature $\left(23 \pm 2^{\circ} \mathrm{C}\right)$ with $12 \mathrm{~h}$ light - dark cycle. The animals were divided into two groups of fifteen mice each. Each group was further divided into control and four treated groups withthree mice in each to represent control, 500mg, $1000 \mathrm{mg}, 2000 \mathrm{mg}$, and $4000 \mathrm{mg}$ concentration of the extract in each method. The control group received olive oil, administered by gavage through oral rout for fifteen days.

\section{Selection and preparation of stock solution for toxicity study}

The n-hexane extract of the plant was suspended in olive oil to prepare four doses of 500, 1000, 2000 and 4000mg according to animal body weight.Control group was administered with $1 \mathrm{ml} / \mathrm{kg}$ olive oil. For $500 \mathrm{mg} / \mathrm{kg}$ of plant extract, by dissolving $50 \mathrm{mg}$ of plant extract per one $\mathrm{ml}$ of olive oil,the stock solution was prepared and dose was injected as $1 \mathrm{ml} / 100 \mathrm{~g}$. For $1000 \mathrm{mg} / \mathrm{kg}$ dose of each plant extract, $100 \mathrm{mg}$ of plant extract was dissolved per $1 \mathrm{ml}$ of olive oil. Similarly 2000 and $4000 \mathrm{mg} / \mathrm{kg}$ of plant extract were prepared by dissolving 200 and $400 \mathrm{mg}$ of plant extract per $1 \mathrm{ml}$ of olive oil respectively.

\section{Acute toxicity}

The animals were observed for $24 \mathrm{~h}$ after administering the extract.

\section{Subacute toxicity}

Subacute toxicity was observed in all the groups received 500, 1000, 2000 and $4000 \mathrm{mg} / \mathrm{kg}$ by gavage for 15 days (once a day). The animals were weighed on daily basis. At the end of experiment animals were sacrificed and blood sample was collected for biochemical analysis. After blood collection, the animals' livers were removed for histopathology. The biochemical parameters evaluated include alkaline phosphatase (ALP), alanine aminotransferase (ALT), aspartate amino transferase (AST), total bilirubin, albumin, protein and globulin.

\section{Statistical analysis}

The results were presented as mean \pm S.D. and the statistical significance between the groups was analyzed by means of the analysis of variance (one way ANOVA).

\section{RESUltS AND DisCUSSIONS}

Oral administration of n-hexane extract of E. laevis in doses from $500-4000 \mathrm{mg} / \mathrm{Kg}$ did not produce significant changes in breathing, behavior, gastrointestinal effects, and sensory nervous system effects in female albino mice. The effects were observed during the experimental period of (24h). No death occurred in any group during first $24 \mathrm{~h}$ of experiment. These results showed that there was no adverse effect of E.laevis in acute doses, indicating that the median lethal dose (LD50) was higher than $4000 \mathrm{mg} / \mathrm{kg}$ for mice.

The results showed that n-hexane extract of E.laevis is safe in oral administration in acute doses in mice. The multiple administrations with the extract did not decrease water and food consumption (data not shown). The body weight of animals treated with n-hexane extract once a day during 15 days (subacute treatment) did not show any significant change when compared with the control group.

Microscopic analysis of target organ of different animals showed changes in liver structure in comparison with the control group. The extract also showed significant increase in ALP, ALT, AST, 
bilirubin and globulin values whereas albumin and protein values decreased to some extent (Table 1, Figure 1, 2 and 3). It was also in accordance with the histopathological study, in which control group was compared with theEhretialaevis n- hexane extract.Histopathological studies showed cell aggregates in parenchyma and blood vessels vicinity, at $1000 \mathrm{mg} / \mathrm{kg}$. At $2000 \mathrm{mg} / \mathrm{kg}$ vacuolation was present, sinusoidal spaces absent, acute cellular swelling, less degree of cell necrosis. At $4000 \mathrm{mg} / \mathrm{kg}$ cellular swelling increased due to sinusoidal spaces, large no. of polymorphic cells were present in blood vessels cells, providing evidence for process of necrosis there. Extracts showed dose related effects on hepatotoxicity. The results were statistically significant.

Conclusion:It was concluded from above mentioned results that plant leaves caused some degree of hepatotoxic injury. Toxicity induced was directly proportional to injected dose i.e. higher the dose greater was the toxicity. However more studies are needed to evaluate chronic toxic effects of Ehretialaevis.

\section{Conflict of interest statement}

We declare that we have no conflict of interest.

Table 1.Effect of treatment with E.laevis n-hexane extract on biochemical parameters

\begin{tabular}{|c|c|c|c|c|c|}
\hline $\begin{array}{c}\text { Dose } \\
\mathbf{m g} / \mathbf{k g}\end{array}$ & $\begin{array}{c}\text { Control } \\
(\mathbf{n = 5})\end{array}$ & $\begin{array}{c}\mathbf{5 0 0 m g} \\
(\mathbf{n = 5})\end{array}$ & $\begin{array}{c}\mathbf{1 0 0 0 m g} \\
(\mathbf{n = 5})\end{array}$ & $\begin{array}{c}\mathbf{2 0 0 0 m g} \\
(\mathbf{n = 5})\end{array}$ & $\begin{array}{c}\mathbf{4 0 0 0 m g} \\
(\mathbf{n = 5})\end{array}$ \\
\hline $\begin{array}{c}\mathrm{ALP} \\
(\mathrm{U} / \mathrm{L})\end{array}$ & $253.40 \pm 2.07$ & $445.80 \pm 9.26$ & $426.2 \pm 28.5$ & $427 \pm 17.04$ & $483.2 \pm 19.66$ \\
\hline $\begin{array}{c}\mathrm{ALT} \\
(\mathrm{U} / \mathrm{L})\end{array}$ & $32.60 \pm 1.673$ & $58.40 \pm 6.50$ & $64.20 \pm 0.447$ & $63.60 \pm 3.36$ & $68.80 \pm 4.09$ \\
\hline $\begin{array}{c}\text { AST } \\
(\mathrm{U} / \mathrm{L})\end{array}$ & $13.80 \pm 1.304$ & $26.60 \pm 4.16$ & $21.60 \pm 5.90$ & $22.20 \pm 2.49$ & $27.60 \pm 5.50$ \\
\hline $\begin{array}{c}\text { Bilirubin } \\
\text { total }\end{array}$ & $0.640 \pm 0.1140$ & $0.8000 \pm 0.0000$ & $0.800 \pm 0.1225$ & $0.8200 \pm 0.0837$ & $0.86 \pm 0.1342$ \\
\hline Albumin & $3.740 \pm 0.894$ & $3.0800 \pm 0.1095$ & $3.200 \pm 0.000$ & $3.200 \pm 0.000$ & $3.200 \pm 0.000$ \\
\hline Protein & $6.92 \pm 0.0837$ & $6.500 \pm 0.300$ & $6.760 \pm 0.0548$ & $6.720 \pm 0.2049$ & $6.700 \pm 0.1225$ \\
\hline Globulin & $3.12 \pm 0.0447$ & $3.580 \pm 0.1643$ & $3.340 \pm 0.1517$ & $3.420 \pm 0.1643$ & $3.6200 \pm 0.2168$ \\
\hline
\end{tabular}

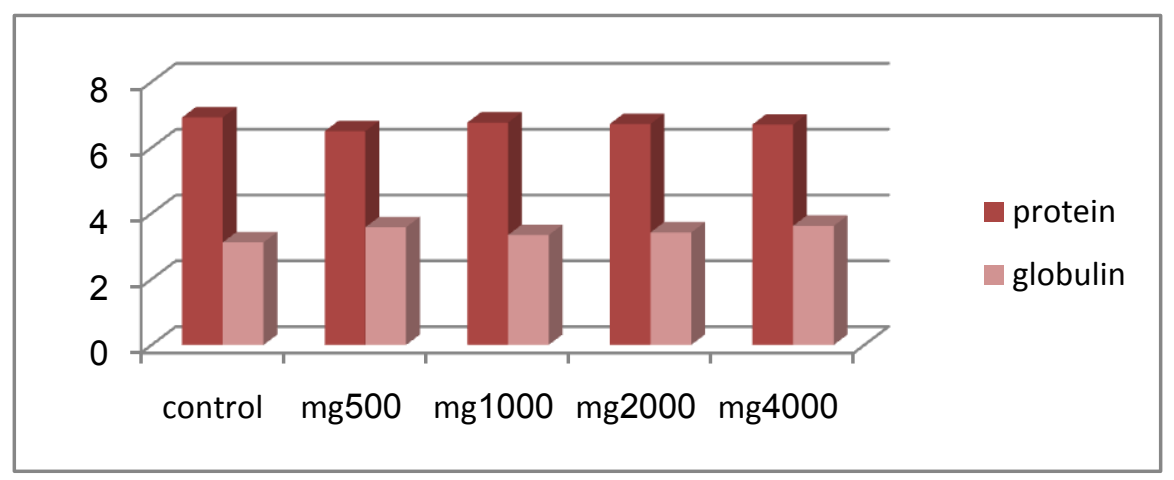

Figure 1.Effects of n-hexane plant extract of Ehretialaevis(leaves) on protein and globulin on female mice.

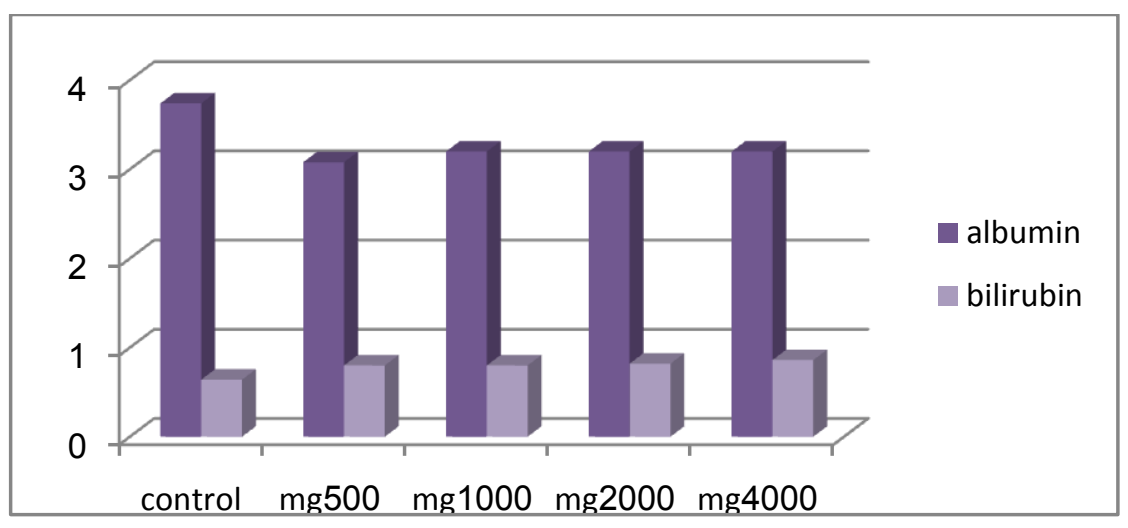

Figure 2.Effects of n-hexane plant extract of Ehretialaevis(leaves) on albumin and bilirubin on female mice. 


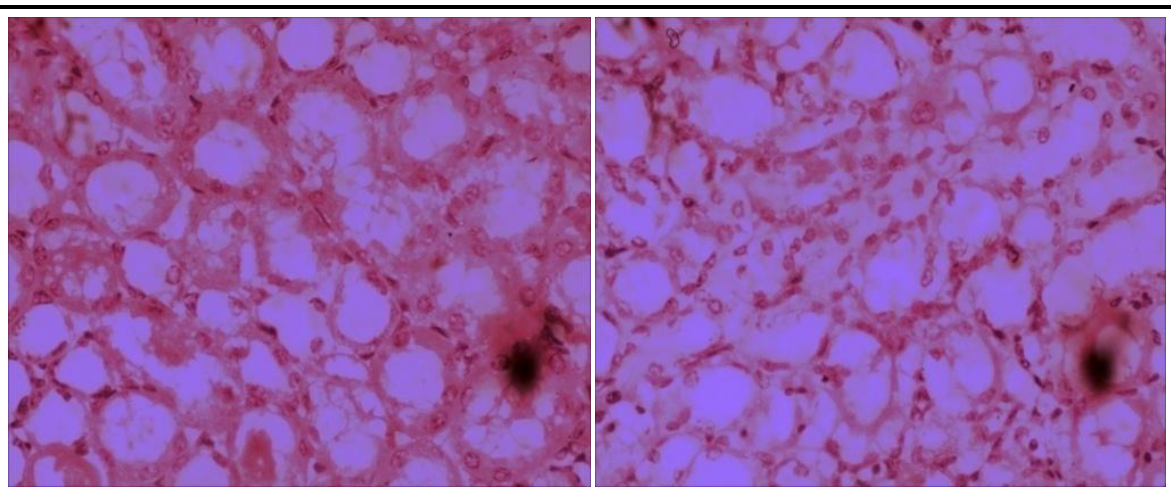

Figure 3. Control group

Figure 4. $500 \mathrm{mg} / \mathrm{kg}$

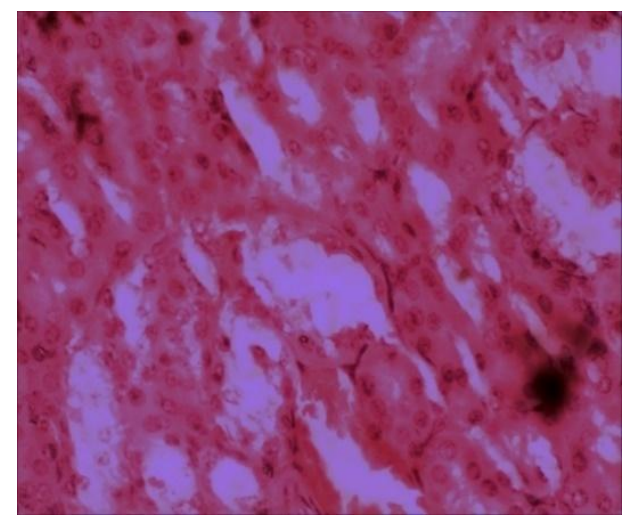

Figure 5.1000mg/kg

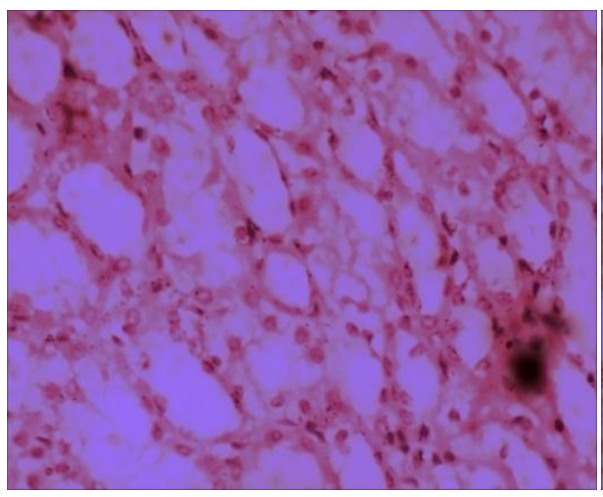

Figure6. $2000 \mathrm{mg} / \mathrm{kg}$

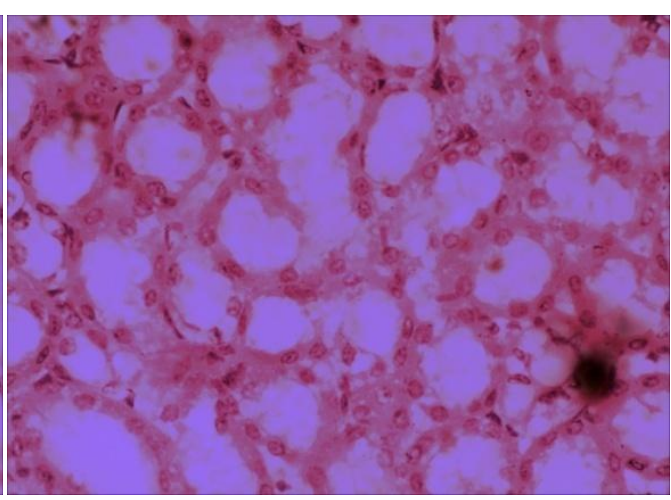

Figure 7. 4000mg/kg

\section{REFERENCES}

Ahmad B, Alam T, Varshney M, Khan, S (2002). Hepatoprotective activity of two plants belonging to Apiaceae and Euphorbiaceae family, J.Ethnopharmacology., 79: 313-316.

Jain A, KatewaS,Galav P (2008). Therapeutic Uses of Biodiversity ByTribalsOf Rajasthan. Ind. J traditional knowledge., 7(2): 259- 260.

Joshi SG (2000). Medicinal plants, Oxford and IBH publishing Co.Pvt.Ltd. New Delhi 102.

Olasehinde G, Ayanda O, AjayiA, NwabuezeA(2012). In-vivo antiplasmodial activity of crude nhexane andethanolic extracts of Moringaoleifera (LAM) seeds onPlasmodiumberghei. Int. J. Med. Plants. Res., 1(5): 050-054.

RasikaC,Gayatri S, Kamble, Sujata V, Upadhye A, Nirmala R, Deshpande I (2011). In-vitro antioxidative activityof phenolic and flavonoid contents of leaves of medicinal plant Ehretialaevis.Int. J. pharma.bio sci., 2(1):810-815.

Rosalki SB, Mcintyre N (1999). Biochemical investigations in the management of liver disease.Oxford Textbook of Clinical Hepatology, New York: Oxford University Press, 2nd Edition, 503-521. 
Saleem M, Irshad I, BaigM,Naseer F(2015). Evaluation of hepatoprotective effect of chloroform and methanol extracts of Opuntiamonacantha in paracetamol-induced hepatotoxicity in rabbits. Bang. J. Pharm., 10: 16-20. 26.

Saleem, M, NaseerF(2014). Medicinal plants in the protection and treatment of liver diseases. Bang. J. Pharm., 10: 511-26.

Sharma A, Jyotsana S, Gairola J, Sumeet N, Gaur R,Painuli R (2012). The treatment of jaundice with medicinal plants in indigenous communities of sub-Hamalayan region of Uttarkhand, India.J. Ethnopharmacology,143: 262-291.

ToraneC, Kamble R, Gayatri S, Khatiwora K, Eliza T, Ghayal K, Nevedita A, Deshpande F,Nirmala R (2011). Antioxidant capacity of leaves and stem of Ehretialaevis.Inter. J. Pharm. \& Pharmaceutical Sci., 3(2):149-151.

Torane R, Kamble G, Chandrachood P, Deshpande N (2010). Preliminary phytochemical screening and nutritional analysis of leaves of Ehretialaevis, J.Pharm.Res.,3(6): 1384-1385. 